\title{
WE ARE THE GRATEFUL DEAD
}

\section{Mark Braunias}

Between late August and October 2019 I completed a visiting artist residency programme at the Dunedin School of Art. This culminated in an exhibition held at the School's gallery between 14 October and I November of the same year.

The exhibition, "Working on a Guru (A Pictorial Procession)," was a deliberately skewed non-linear and ironic interpretation of leaders and followers or cults throughout Western history. An emphasis was placed on the notion of spiritual belief systems, and the work referenced Giotto's Arena Chapel frescoes as a site from which to decontextualise.

Within this re-invented chapel an entire end wall arrangement, We are the Grateful Dead, operated as a standin for The Last Judgment. Typed obituaries of significant or famous people (both positive and negative in terms of their reputation) were presented in encyclopedic book form and arranged in alphabetical order. The altered photographs of each individual were given hand-drawn frames alluding to the process of biological and molecular deconstruction. These frames included abstracted biological parts and cell structures such as mitochondrion, ribosomes, microtubules, vacuoles, nucleus and nucleoli - essentially molecules and atoms actively disassembling and reassembling. The written commentary alluded to the subjects' life achievements (or otherwise), with a final sentence which was often little more than an ironic and pithy 'summing up.'

Following the exhibition, I decided to bring many of the deceased in these works back to life - perhaps to offer them another chance at even greater immortality. Establishing an Instagram account for my famous dead, I regenerated the same altered photographs from the exhibition and uploaded them to a contemporary online platform - the assumption being that they would still feel the need to communicate via impassioned posts from beyond the grave. The Internet's global coverage offered the grateful dead vast opportunities to convert the masses, possibly plead for forgiveness or, more than likely, maintain a similar pose to that revealed in their own era.

Satire is obviously the key driver for the entire concept and yet, despite a mocking tone, the message delivered by the famous dead attempts to convey a 'darkened' universal empathy and need. This need is at the heart of the works spread across the following pages. It's a need to be noticed, to be understood, to be respected, to be popular and potentially to be adored. Finally, like all Instagram or Facebook users, a need to know you actually exist. Or not.

Mark Braunias graduated from Canterbury University with a BFA in 1988. He has exhibited widely in New Zealand and overseas since that time. In 2019 Braunias completed an Artist Residency at the Dunedin School of Art. For further information : markbraunias.com 


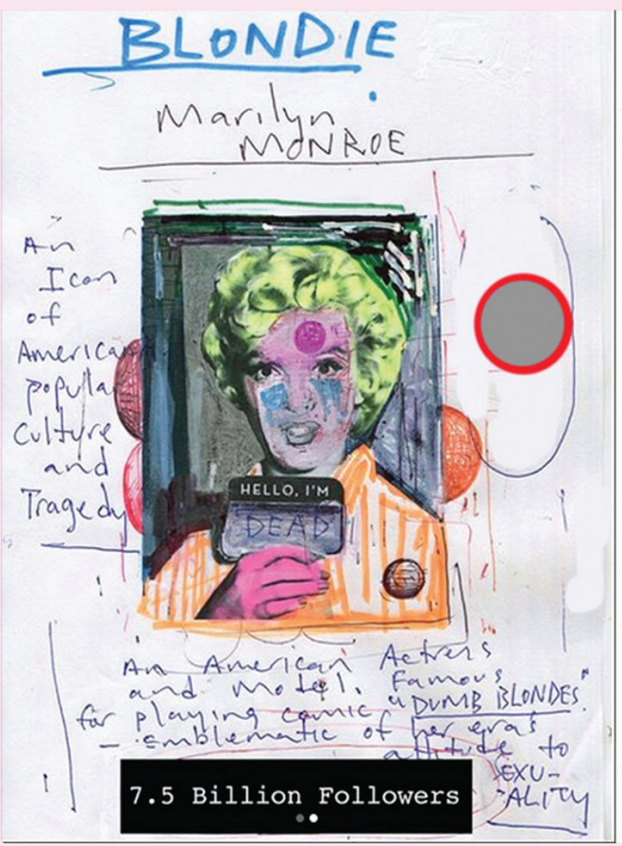

cult_followers

....... Hey All! They say some like it hot but I'm telling ya, it's way beyond that where I am lord where is JFK when you need him. Him and his bros just give me the cold shoulder these days $*$. Elvis and his Memphis Mafia buddies are total dicks and even Arthur Miller is a loser. Death of a salesman? Give us a break! Being dead is a dead loss.lol. Blow a candle in the wind for me will ya

Marilyn Monroe (June 1, 1926 - August 4 1962).

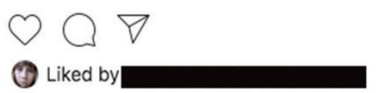

OCTOBER 25, 2019

Add a comment...

$\ldots$

ఎ

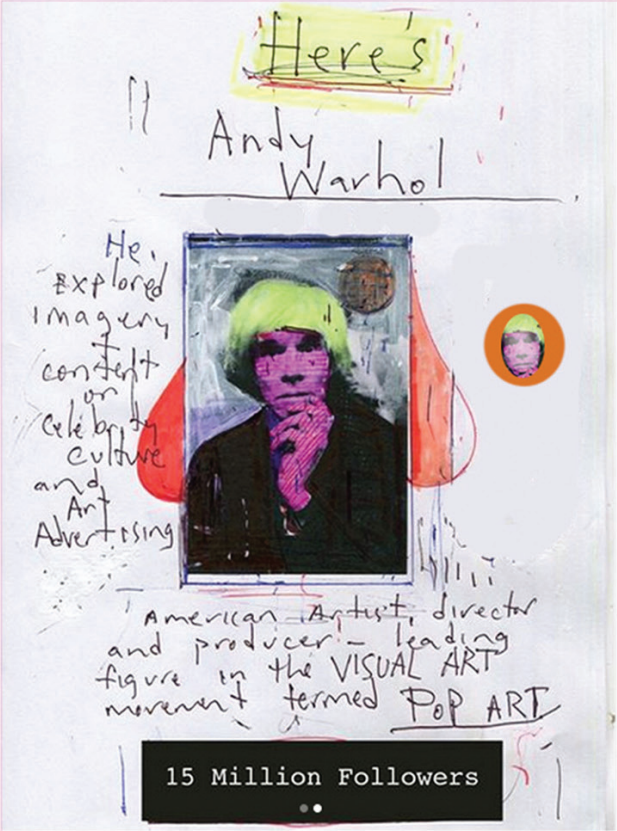

cult_followers

$\cdots$

....... Oh gee... like hi... you guys are just s00000 amazing $(\theta)$. Really. I am just s00000 jealous and everything. It's like you guys are just EVERYWHERE!!!! All I got in my day was a lousy 15 minutes of fame. 15 minutes! That just so sucks $\Theta$. I never even had 1 like. Like I had nothing! It's so unfair. I wannabe somebody too you know. I even got shot one time as well. Surely that must count for something? Oh rats, darn it all, you guys are just so lucky $\otimes$.

Andy Warhol (1928-1987)

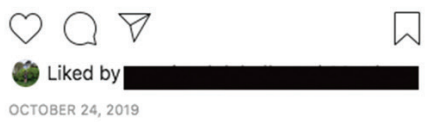

OCTOBER 24, 2019 

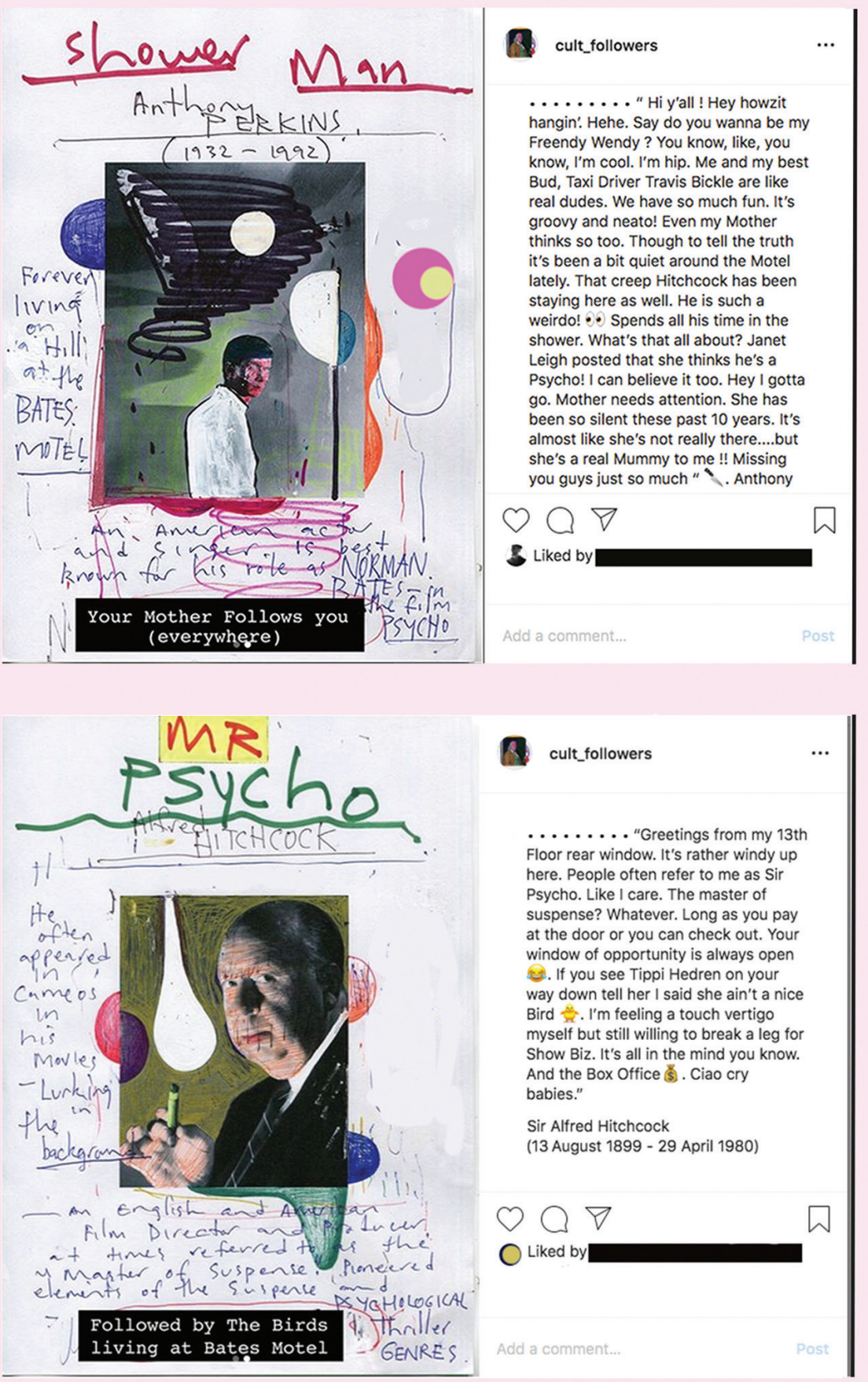

cult_followers

....... "Greetings from my 13 th Floor rear window. It's rather windy up here. People often refer to me as Sir Psycho. Like I care. The master of suspense? Whatever. Long as you pay at the door or you can check out. Your window of opportunity is always open 6. If you see Tippi Hedren on your way down tell her I said she ain't a nice Bird $\frac{3}{\mathrm{~s}}$. I'm feeling a touch vertigo myself but still willing to break a leg for Show Biz. It's all in the mind you know. And the Box Office 5 . Ciao cry babies."

Sir Alfred Hitchcock

(13 August $1899-29$ April 1980)

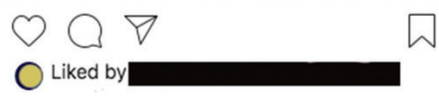

Liked by 


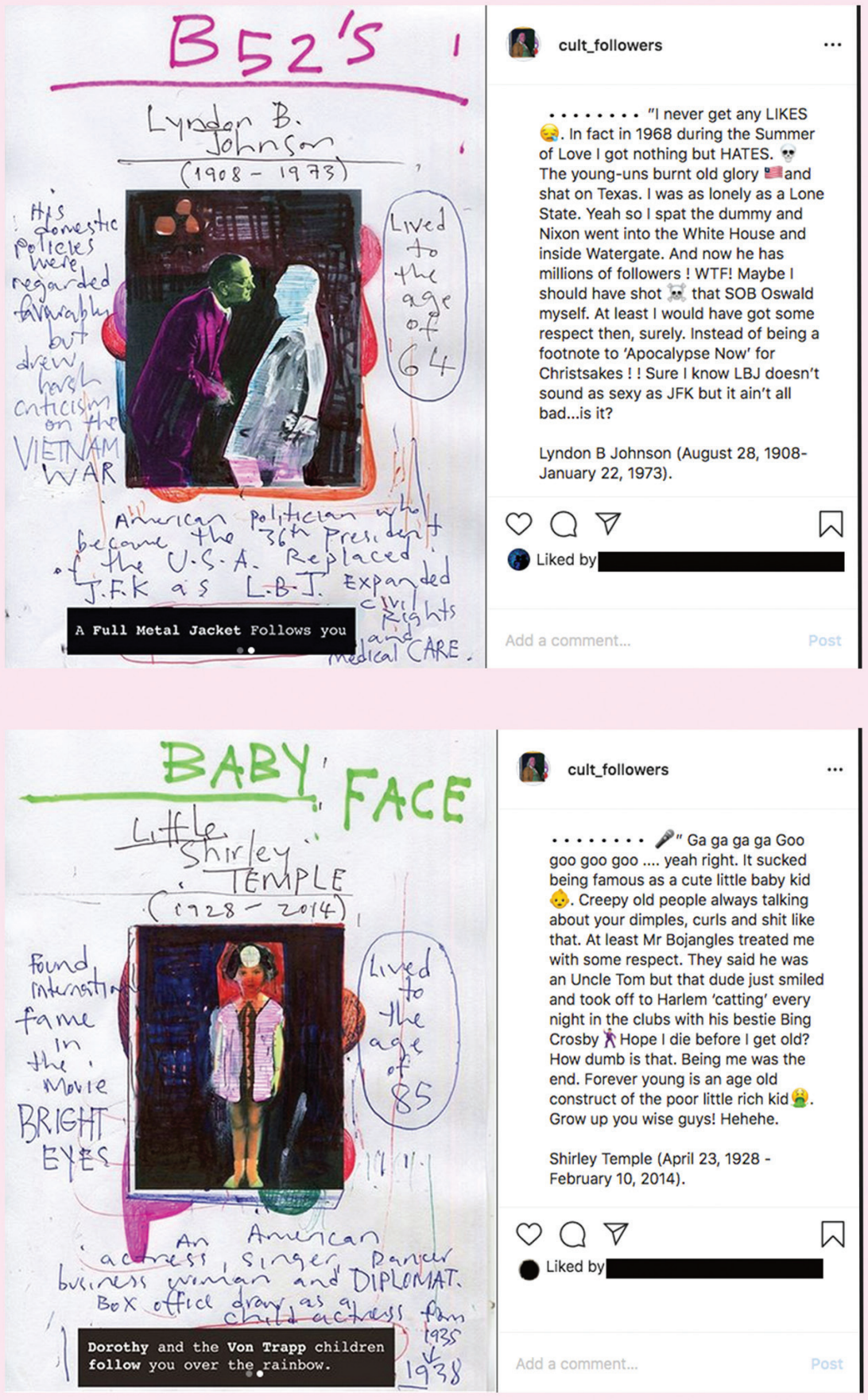




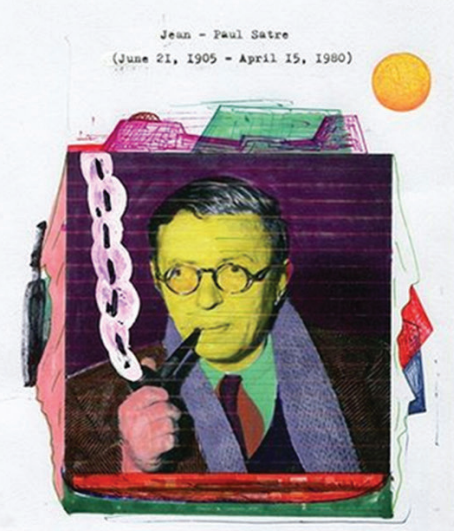

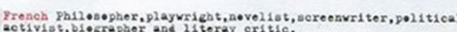

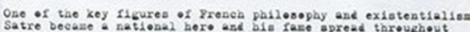

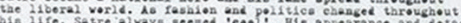
-

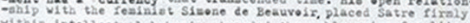

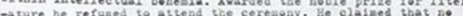

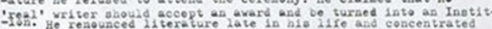

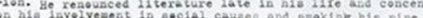

\section{Simone de Beauvoir Follows you} (and Significant Others)

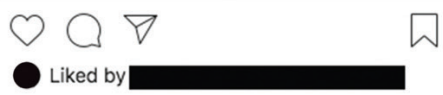

Simone de Beauve 1

(January 9, I908 - ApriI I4, I986)
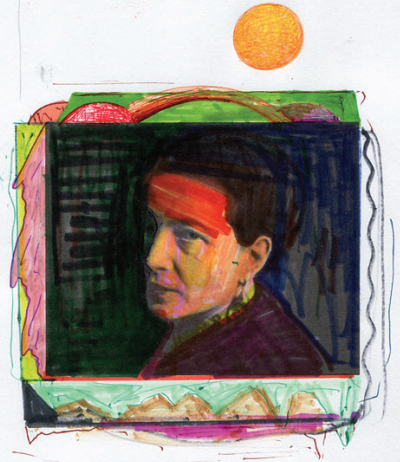

French Writer, intellectual, existential
activist, feminist and social theorist.

Simene de Beauvoir 18 known for ner troatise ' detalled analysis on wemen's oppression and a foundation tract family and rebelled as a teenager, losing her faith ane remaining

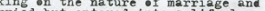
soul partnership -vershadowed her lit terary work she aryued that mon the other, beacuse of the perception of relationshipa. She reas- ined independent and

Jean Paul Satre Follows you (and Significant others) cult_followers

........ "Good morning starshine

So happy to be (es)

My love and me as we singing

Our early morning singing song

Gliddy glub gloopy, nibby nabby nooby la la la lo lo

Sabba sibby sabba nooby abba nabba le le lo lo

Tooby ooby walla nooby abba naba

Good morning starshine

The earth says hello!

Jean Paul Sartre (June 21, 1905 - April 15,1980 ) channeling the American counter culture in the summer of 1969 whilst having an existential wig out.

Add a comment...

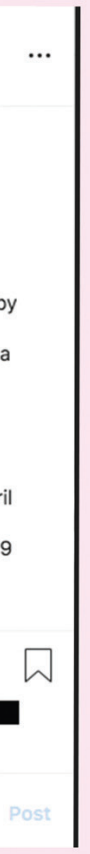

cult_followers

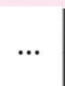

....... "Good morning starshine

So happy to be

My love and me as we singing

Our early morning singing song

Gliddy glub gloopy nibby nabby nooby la la la lo lo

Sabba sibby sabba nooby abba naba le le lo lo

Tooby ooby walla nooby abba naba

Good morning starshine

Mother earth says hello!

Simone de Beauvoir (January 9, 1908April 14, 1986) channeling Marcia!

Marcia! Marcia! of The Brady Bunch in the episode "The Jealous Sister"

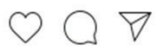

Liked by 